\title{
Novel quantitative analysis of the S100P protein combined with endoscopic ultrasound-guided fine needle aspiration cytology in the diagnosis of pancreatic adenocarcinoma
}

\author{
MASAFUMI CHIBA ${ }^{1}$, HIROO IMAZU ${ }^{1}$, MASAYUKI KATO ${ }^{1}$, KEIICHI IKEDA ${ }^{1}$, HIROSHI ARAKAWA ${ }^{1}$, \\ TOMOHIRO KATO $^{1}$, KAZUKI SUMIYAMA ${ }^{1}$ and SADAMU HOMMA $^{2}$ \\ Departments of ${ }^{1}$ Endoscopy and ${ }^{2}$ Oncology, The Jikei University School of Medicine, Tokyo 105-8461, Japan
}

Received November 7, 2016; Accepted December 19, 2016

DOI: $10.3892 /$ or.2017.5471

\begin{abstract}
Specimens obtained with endoscopic ultrasound-guided fine needle aspiration (EUS-FNA) are often tiny and fragmented leading to an inconclusive and doubtful diagnosis. To overcome the limitations of EUS-FNA in the cytological diagnosis of pancreatic adenocarcinoma (PCA), we evaluated whether quantification of the S100P protein combined with EUS-FNA reliably discriminated between PCA and benign pancreatic lesions (BPL). A high sensitivity sandwich ELISA for S100P protein was developed to aid in the detection of PCA in small samples obtained using EUS-FNA. After experimental verification of the sandwich ELISA with cell lines and mouse xenograft tumors, 27 consecutive patients with suspicious PCA who underwent EUS-FNA were enrolled in the present study examining the combination of S100P protein assessment and EUS-FNA cytology. The concentration of the S100P protein in EUS-FNA samples from the PCA group was significantly higher than that in the BPL group $(\mathrm{P}=0.04)$. Using receiver operating characteristic curve analysis, we determined the S100P protein cut-off value for PCA diagnosis to be $99.8 \mathrm{ng} / \mathrm{ml}$. The $\mathrm{S} 100 \mathrm{P}$ protein levels combined with EUS-FNA cytology to detect PCA showed the following diagnostic values: sensitivity, 94.4\% [95\% confidence interval (CI), 75.7-99.1\%]; specificity, 88.9\% (95\% CI, 51.8-99.7\%); positive predictive value, $94.4 \%$ (95\% CI, 72.7-99.9\%); negative predictive value, $88.9 \%$ (95\% CI, 51.8-99.7\%); accuracy, $92.6 \%$ (95\% CI, 75.7-99.1\%); and area under the curve, 0.92 (95\% CI, 0.79-1.00). We established a novel quantitative analysis for the S100P protein in EUS-FNA samples which, when combined with EUS-FNA cytology, could provide promising results for the reliable diagnosis of PCA.
\end{abstract}

Correspondence to: Dr Masafumi Chiba, Department of Endoscopy, The Jikei University School of Medicine, 3-25-8 NishiShinbashi, Minato-ku, Tokyo 105-8461, Japan

E-mail: cc10972009720@gmail.com

Key words: pancreatic adenocarcinoma, quantitative analysis, S100P protein, endoscopic ultrasound-guided fine needle aspiration, clinical trial

\section{Introduction}

Endoscopic ultrasound-guided fine needle aspiration (EUS-FNA) is reported to be a safe and useful method for obtaining diagnostic tissue samples in cases of suspicious pancreatic adenocarcinoma (PCA) (1). However, specimens obtained with EUS-FNA are often tiny and fragmented leading to an inconclusive and doubtful diagnosis in up to $20 \%$ of patients with PCA (2-4). A variety of factors, such as desmoplastic reaction in PCA associated with poor cellularity (4-8), difficulty in discriminating between well-differentiated PCA and reactive atypia $(9,10)$, and technical aspects of EUS-FNA (11-15), may lead to inconclusive or doubtful diagnoses in small EUS-FNA samples. In addition, the sensitivity of EUS-FNA for PCA ranges widely from 44 to $100 \%(1,16)$, and the negative predictive value (NPV) also shows an enormous spread (16-92\%) (17). Thus, negative results cannot completely exclude malignancy, and diagnosing PCA using EUS-FNA is still challenging.

PCA is characterized by a variety of molecular alterations, and molecular and biological markers for diagnosing PCA have been developed. Among these markers, S100P has been noted as a detection marker for PCA $(18,19)$. S100P is specifically expressed in PCA cells with a high frequency (10,19-27). Moreover, a meta-analysis investigating whether S100P can detect PCA using EUS-FNA or surgical specimens showed a pooled sensitivity, specificity, and area under the receiver operating characteristic (ROC) curve (AUC) of 87\% [95\% confidence interval (CI), 83-90\%], 88\% (95\% CI, 82-93\%) and 0.927 , respectively (28).

However, these studies assessing S100P in EUS-FNA samples used mRNA quantification or immunohistochemical (IHC) analysis (10,19,21-27,29). When samples are collected from pancreatic lesions by EUS-FNA, there is a potential risk that mRNA is exposed to RNase digestion, resulting in the fragmentation of mRNA $(4,22,30)$. In addition, IHC analysis can only be achieved, when an adequate amount of EUS-FNA sample is obtained (4,29). Thus, detection of S100P using mRNA quantification or IHC analysis from EUS-FNA samples has limitations, and hence, a detection method for S100P in small EUS-FNA samples is needed.

There have been no studies on the assessment of the S100P protein itself in any pathological samples, including EUS-FNA, 
surgical and serological samples. Thus, the quantification of the S100P protein itself may overcome the limitations observed with mRNA and IHC analysis in small pancreatic samples obtained by EUS-FNA, and provide promising results for the diagnosis of PCA.

Therefore, the aim of the present study was to establish a novel, simple system of quantifying the S100P protein even in small EUS-FNA samples and evaluate whether quantitative analysis of the S100P protein combined with EUS-FNA cytology can provide a reliable diagnosis for PCA.

\section{Materials and methods}

The present study consisted of 3 parts: i) the ex vivo development of a high sensitivity sandwich ELISA for the S100P protein as a quantitative analysis for detecting small amounts of PCA cells in tiny EUS-FNA samples, ii) the in vivo evaluation of this newly developed assay using cell lines and mouse xenograft tumors, iii) a pilot clinical trial to investigate the efficacy of S100P protein assessment combined with EUS-FNA cytology for the diagnosis of PCA.

Ethics statement. All mice used in the present study were cared for according to animal care regulations of national and international guidelines (The National Institutes of Health Guide for the Care and Use of Laboratory Animals and the ARRIVE Guidelines). Animal protocols were approved by the Animal Care Committee of the Jikei University School of Medicine (identification no. 24-044). All efforts were made to minimize suffering.

The clinical trial was approved by the Human Subjects Committee at the Jikei University School of Medicine [identification no. 26-109 (7614)], and was subsequently registered with the University Hospital Medical Information Network (UMIN) Clinical Trials Registry (identification no. UMIN000015871). The clinical trial was conducted in accordance with the Declaration of Helsinki. All participants provided written informed consent to participate in the study.

Development of a quantitative determination method for the S100P protein

Microplates, standard antigens, antibodies and reagents for the S100P sandwich ELISA. For the ex vivo analysis, we utilized 96-well Optimiser ${ }^{\mathrm{TM}}$ microplates and their accompanying reagents, which were purchased from Siloam Biosciences, Inc. (Cincinnati, OH, USA). His-tagged human recombinant S100P (1-95) (no. ATGP 0565) was used as the standard antigen and was purchased from ATGen Co., Ltd. (Seongnam-si, Gyeonggi-do, Korea). S100P rabbit monoclonal antibody (no. GTX63569) was used as the capture antibody (GeneTex Inc., Irvine, CA, USA), and human S100P monoclonal antibody was used as the detection antibody (no. MAB2957; R\&D Systems Inc., Minneapolis, MN, USA). Biotin, for labeling the detection antibody and Sample Diluent Concentrate $2^{\mathrm{TM}}$ (no. DYC002) were also purchased from R\&D Systems. Leupeptin (no. L8511) was purchased from Sigma-Aldrich (St. Louis, MO, USA) and aprotinin from bovine lung (no. 018-18111) was purchased from Wako Pure Chemical Industries Ltd. (Osaka, Japan). To make solubilized samples for the S100P ELISA, we originally produced a new buffer named 'Lysis Buffer No. 9' which consisted of $1 \%$ NP-40 alternative, $20 \mathrm{mM}$ Tris, $137 \mathrm{mM} \mathrm{NaCl}, 10 \%$ glycerol, $2 \mathrm{mM}$ EDTA, $1 \mathrm{mM}$ activated sodium orthovanadate, $10 \mu \mathrm{g} / \mathrm{ml}$ aprotinin and $10 \mu \mathrm{g} / \mathrm{ml}$ leupeptin.

Assessment of total protein concentration in each sample by bicinchoninic acid (BCA) protein assay prior to S100P protein analysis. To determine the effective dilute concentration of the solubilized samples for S100P protein analysis, and to evaluate whether human EUS-FNA samples contained cell components and could be useful as a rapid on-site test, total protein concentrations in the solubilized samples were analyzed by the BCA protein assay, using the Micro $\mathrm{BCA}^{\mathrm{TM}}$ Protein Assay kit (no. 23235) purchased from Thermo Fisher Scientific Inc. (Waltham, MA, USA). The total protein concentration of each sample was determined by an absorbance plate reader (XR680TM; Bio-Rad Laboratories Inc., Hercules, CA, USA), according to the manufacturer's instructions.

S100P protein assessment protocol by sandwich ELISA. According to the total protein concentration results, each solubilized sample was diluted to an effective assessment range by adding sandwich ELISA blocking buffer (no. OM-055; Siloam Biosciences, Inc.); for cell lines and xenograft tumors, dilutions were to 500,100 and $50 \mu \mathrm{g} / \mathrm{ml}$ of protein, and for human samples to $50,25,12.5,6.25,3.13,1.56$ and $0.78 \mu \mathrm{g} / \mathrm{ml}$ of protein.

Using the same conditions described in the manufacturer's users manual for human vascular endothelial growth factor (Document ID: ETS-1-MS-0011-A1; Siloam Biosciences, Inc.), a 96-well Optimiser ${ }^{\mathrm{TM}}$ microplate was coated with GTX63569 as a capture antibody and blocked. S100P standard antigen or solubilized samples were dispensed to each well, then biotinylated MAB2957 was added as the detection antibody. After the accompanying horseradish peroxidase and fluorescent substrate were added, fluorescence intensity was assessed using a fluorescence plate reader (2300 EnSpire ${ }^{\mathrm{TM}}$; PerkinElmer, Inc., Waltham, MA, USA) with an excitation wavelength of $570 \mathrm{~nm}$ and an emission wavelength of $585 \mathrm{~nm}$. Finally, the concentration of S100P protein in the samples was determined by comparison to the standard curve. This protocol was performed twice, and the concentrations of S100P protein were averaged.

Quantification of the S100P protein in cell lines and xenograft tumors

Cell line preparation for the assessment of the S100P protein. AsPC-1, PANC-1 and MIA PaCa-2 were used as human PCA cell lines. MCF-7 (a human breast cancer cell line), known as an S100P-expressing tumor, was also used as a positive control for S100P. Fibroblasts obtained from the primary culture of PCA, hTERT-HPNE E6/E7/K-RasG12D/st human normal pancreatic duct epithelium [hTERT1, no. CRL4039; American Type Culture Collection (ATCC), Manassas, VA, USA] and human umbilical vein endothelial cells (HUVECs, no. C12208; PromoCell GmbH, Heidelberg, Germany) were used as non-cancerous cell lines.

FNA sampling of xenograft tumors from mice to quantify the S100P protein. PANC-1 ( $2 \times 10^{6}$ cells/mouse), MIA PaCa-2 $\left(2 \times 10^{6}\right.$ cells/mouse) and AsPC-1 $\left(1 \times 10^{6}\right.$ cells/mouse $)$ were 
subcutaneously inoculated into the back of two 6- to 8-week-old female NOD/ShiJic-scid mice (Clea Japan Inc., Tokyo, Japan). All mice were maintained under controlled conditions (specific pathogen-free conditions, $22^{\circ} \mathrm{C}, 55 \%$ humidity, 12-h light/dark cycle), with food and water ad libitum, in groups of $2 /$ cage. Tumor growth was monitored weekly by caliper measurements. Animal husbandry and daily care were provided by veterinary technicians. When a tumor grew to $15 \mathrm{~mm}$, the maximum diameter, the mice were sacrificed by occipital dislocation under general anesthesia. Xenograft tumor tissues were then sampled with an FNA using a 22-gauge needle Expect $^{\mathrm{TM}}$; Boston Scientific, Boston, MA, USA). Each FNA sample was solubilized by adding $\mathrm{x} 2$ the volume of Lysis Buffer No. 9, and incubated on ice for $15 \mathrm{~min}$. After centrifugation at $2,000 \mathrm{x} \mathrm{g}$ for $5 \mathrm{~min}$, the supernatants were transferred to clean test tubes and stored at $-80^{\circ} \mathrm{C}$ until analysis.

\section{Clinical pilot trial in patients with suspicious pancreatic carcinoma}

Patients. After the successful development of the quantitative assay for the S100P protein, consecutive patients with suspicious pancreatic carcinoma who were referred for EUS-FNA sampling at Jikei University Hospital and Jikei University-affiliated institutions were prospectively recruited in this pilot study between October 12, 2014 and September 1, 2016. The inclusion criteria were as follows: i) patients $>20$ years old, ii) provision of written informed consent to participate in the present study, and iii) presence of a suspicious pancreatic carcinoma which was detected by at least a single investigational modality such as computed tomography, magnetic resonance imaging or EUS. The exclusion criteria were as follows: i) internal use of an antiplatelet or anticoagulant agent, ii) bleeding disorders, acute pancreatitis, treatment history of radiology or chemotherapy, iii) inability to sample the lesion due to the presence of intervening blood vessels, and iv) pancreatic lesions such as cystic neoplasms with the risk of peritoneal dissemination by puncture.

Before the trial began, we empirically anticipated that the number of participants required was 30 cases at least to evaluate the feasibility of this novel technology in the phase I trial (31).

Tissue sampling method for EUS-FNA. EUS was performed using a curvilinear echoendoscope (GF-UCT260; Olympus Medical Systems, Tokyo, Japan) under conscious sedation using intravenous midazolam and pethidine with color Doppler ultrasound assistance. EUS-FNA was performed with a 19-, 22- or 25-gauge needle (Expect ${ }^{\mathrm{TM}}$ ) by 5 endosonographers (3 experts and 2 trainees). During a puncture, the needle traversed the lesion to and fro $>10$ times with negative aspiration using a $20 \mathrm{ml}$ syringe. Without on-site evaluation, 2 or 3 EUS-FNA punctures are routinely performed for pancreatic lesions to obtain an adequate specimen for cytological diagnosis at our institution (32). The specimen obtained with one of the punctures was transferred to a clean test tube and immediately stored at $-80^{\circ} \mathrm{C}$ for later quantitative analysis of the $\mathrm{S} 100 \mathrm{P}$ protein, while the remaining specimen obtained with 1 or 2 punctures was used for cytological diagnosis. Thus, for the purpose of evaluating the utility of the S100P protein assessment combined with EUS-FNA cytology, we never performed an additional puncture to obtain the specimen for the S100P protein analysis.
Preparation of EUS-FNA samples prior to the quantification of S100P protein. On the day of analysis, the volume of each EUS-FNA sample was first assessed. Then, the samples were solubilized by adding $\mathrm{x} 2$ the volume of Lysis Buffer No. 9, and incubated on ice for $15 \mathrm{~min}$. When the sample volume was $<10 \mu \mathrm{l}, 10 \mu \mathrm{l}$ of Lysis Buffer No. 9 was added. Following the incubation on ice, the samples were centrifuged at $2,000 \mathrm{x} \mathrm{g}$ for $5 \mathrm{~min}$ and the supernatant was transferred to a clean test tube. Total protein concentrations were then assessed by BCA protein assay prior to quantification of the S100P protein.

Test methods (index test, cut-off value, reference standard). We complied with the Transparent Reporting of Evaluations with Nonrandomized Designs (TREND) statement and the Standards for Reporting Diagnostic Accuracy Studies 2015 (STARD 2015) $(33,34)$. The definition of a positive cytological test was 'V. Suspicious (for malignancy) and VI. Positive/malignant' according to the Papanicolaou Society of Cytopathology Guidelines for pancreatobiliary cytology (35-37). For the S100P protein analysis, the index test represented the concentration of the S100P protein in the human FNA samples. The definition of the index test 'positivity' and the 'cut-off value' were determined from ROC curves. An 'inconclusive' index test represented the inability to quantify the $\mathrm{S100P}$ protein due to a low concentration of total protein $(<10 \mathrm{mg} / \mathrm{ml})$. The reference standard represented the final diagnosis of the pancreatic mass, on the basis of a pathological diagnosis from the surgical specimen or an overall determination from the clinical course with an observation period of $>6$ months.

Outcome measures. In this human trial, the primary end point was the evaluation of the accuracy of the S100P protein quantification combined with EUS-FNA cytology to detect PCA.

Statistical analysis. The Kruskal-Wallis and Mann-Whitney tests were used to evaluate comparisons of S100P protein concentrations among cell lines, xenograft tumors and human EUS-FNA samples. The Mann-Whitney test was also used to evaluate the difference in S100P protein concentrations between patients with PCA and benign pancreatic lesions (BPL). The linear regression test was used to evaluate the correlation between S100P protein concentration and the clinical stage, or the concentration of total protein in human EUS-FNA-samples. ROC curves and AUC were used to assess the diagnostic performance of the quantitative S100P protein analysis alone, and in combination with EUS-FNA cytology. The cut-off value was determined by ROC curve, which revealed the highest sum of sensitivity and specificity for the diagnosis of PCA. A P-value of $<0.05$ was considered significant. All analyses were performed using Stata version 13 (StataCorp LP, College Station, TX, USA).

\section{Results}

Quantitative analysis specific for the S100P protein in an ex vivo experiment. The antibodies (GTX63569 and MAB2957 with biotin labeling) used in the sandwich ELISA exhibited high specificity for the S100P antigen, and cross reactivity with other relevant proteins was not observed. A standard curve was constructed using the S100P standard antigen, 


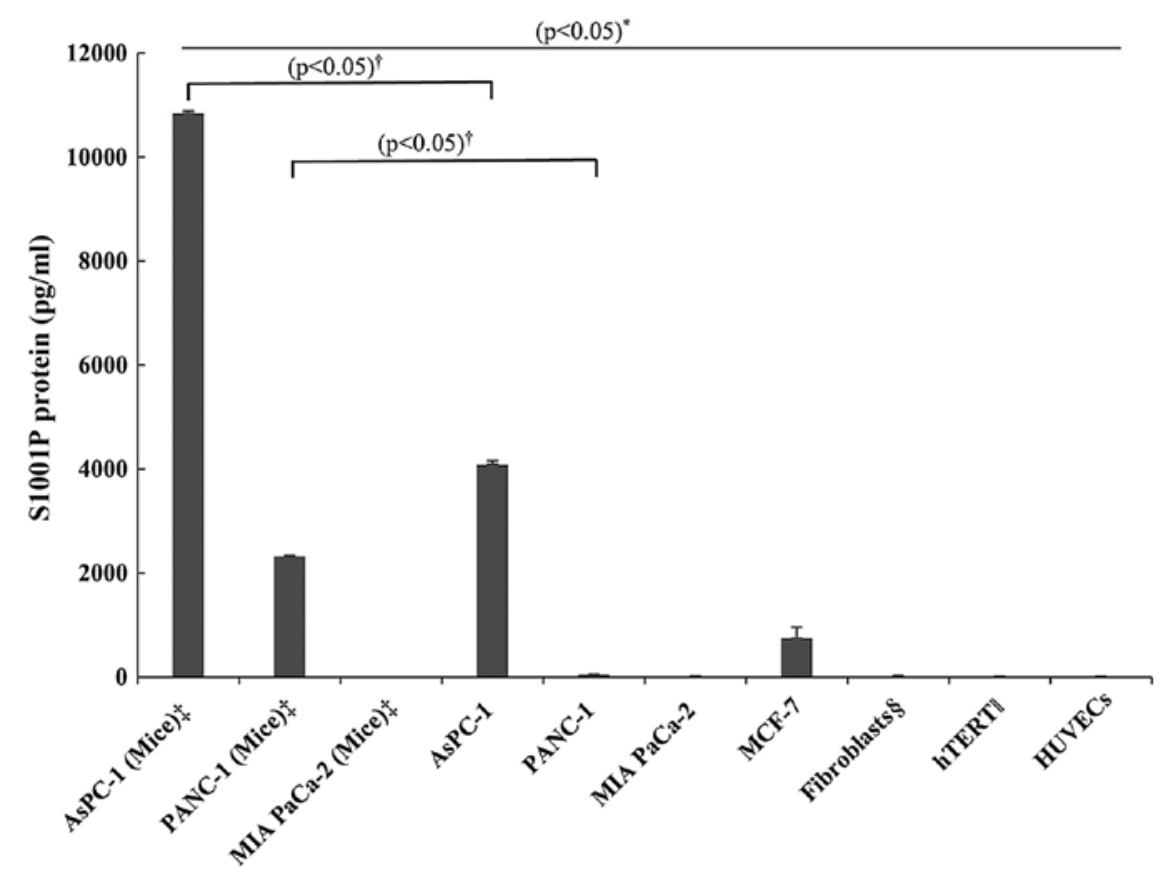

Figure 1. Comparison of S100P concentration in each cell line and each xenograft tumor provided by fine needle aspiration. The concentration of the undiluted solution was calculated in accordance with the dilution rate. "Kruskal-Wallis test. ${ }^{\dagger}$ Mann-Whitney U test. "Fine needle aspiration samples obtained from xenograft mice. ${ }^{8}$ Cancer-associated fibroblasts. "hTERT-HPNE E6/E7/K-RasG12D/st human normal pancreatic duct epithelium.

and a linear approximation equation $(y=157 x+347.38)$ was calculated from the standard curve plot, allowing S100P protein concentrations to be determined in each sample. The effective assessment range of the assay was from 1.5625 to $50.0000 \mathrm{pg} / \mathrm{ml}$ S100P protein.

S100P protein concentrations in cell lines and xenograft tumors. The amount of S100P protein in the cultured cells and xenograft tumors was determined using ELISA (Fig. 1). The S100P protein concentration in AsPC-1 xenograft tumors was higher than that in the AsPC-1 cultured cells, and the concentration in the cultured AsPC-1 cells was higher than that in the MCF-7 cells, the positive control for the S100P protein. Although, the S100P protein was not detected in the cultured PANC-1 cells, the PANC-1 xenograft tumors showed significant $\mathrm{S} 100 \mathrm{P}$ protein concentrations, while the MIA PaCa2 cells had no detectable S100P protein in either the cultured cells or the xenograft tumors. The non-cancerous cells (fibroblasts derived from the PCA primary culture, hTERT1 and HUVECs) also had no detectable S100P protein.

Clinical pilot trial. A total of 41 adult patients with a pancreatic mass were enrolled in the first entry, and 7 patients were excluded due to intraductal papillary mucinous neoplasm $(n=1)$, the presence of intervening blood vessels $(n=5)$ and ascites $(n=1)$. A total of 34 patients underwent diagnostic EUS-FNA. No procedure-related adverse events were observed during the present study. Of the 34 patients that underwent EUS-FNA, 7 patients were excluded due to cytodiagnosis only owing to difficult puncture location or a tiny amount of tissue $(n=5)$, contamination by alcoholic fixative $(n=1)$ and indetermination of final diagnosis $(n=1)$.

Finally, 27 patients were enrolled in the present study, according to the inclusion and exclusion criteria, and cytology and S100P protein analysis were performed on all patients (Fig. 2). The baseline demographic and clinical characteristics of the patients are shown in Table I. There was no patient lost in follow-up in the present study.

The final diagnosis was PCA in 18 patients, chronic pancreatitis in 3, autoimmune pancreatitis (AIP) in 5, and a normal pancreas in 1 . Six patients among the 18 with PCA underwent surgical resection. For the patients with PCA, the clinical stage at the time of enrollment according to the American Joint Committee on Cancer TNM staging was stage IIb in 6 patients, stage III in 1 patient, and stage IV in 11 patients; there were no patients with stage Ia, Ib or IIa in the present study. The mean serum level of CA19-9 and CEA in patients with PCA was $1,465.8 \mathrm{U} / \mathrm{ml}$ and $10.8 \mathrm{ng} / \mathrm{ml}$, respectively, and in patients with BPL it was $232.7 \mathrm{U} / \mathrm{ml}$ and $4.0 \mathrm{ng} / \mathrm{ml}$, respectively.

The S100P protein could not be quantified in the EUS-FNA samples of 5 (3 with PCA, 1 with AIP and 1 with chronic pancreatitis) of the 27 patients due to low total protein concentrations of $<10 \mathrm{mg} / \mathrm{ml}$ (index test inconclusive, Fig. 2). In fact, for these samples, serial dilutions in the range of the assay produced non-linear values for the S100P protein. Thus, EUS-FNA conducted in our routine manner (32) yielded samples that were adequate for S100P protein quantification in 22 of the 27 patients $(81.5 \%)$. In these 22 patients, the S100P protein concentration was assessed as the index test (Fig. 2).

When the 22 patients with a conclusive index test were divided into 2 groups, PCA $(n=15)$ and BPL $(n=7)$ (the latter consisting of 2 patients with chronic pancreatitis, 4 with AIP, and 1 with a normal pancreas), the mean total protein concentration was $75.7 \mathrm{mg} / \mathrm{ml}$ (range, 10.2-155.0 mg/ml) and $43.5 \mathrm{mg} / \mathrm{ml}$ (range, 17.9-70.1 mg/ml), for PCA and BPL, respectively. The mean volume of EUS-FNA sample in the PCA and BPL groups was 61.4 $\mu \mathrm{l}$ (range, 0.5-320.0 $\mu \mathrm{l}$ ) and 


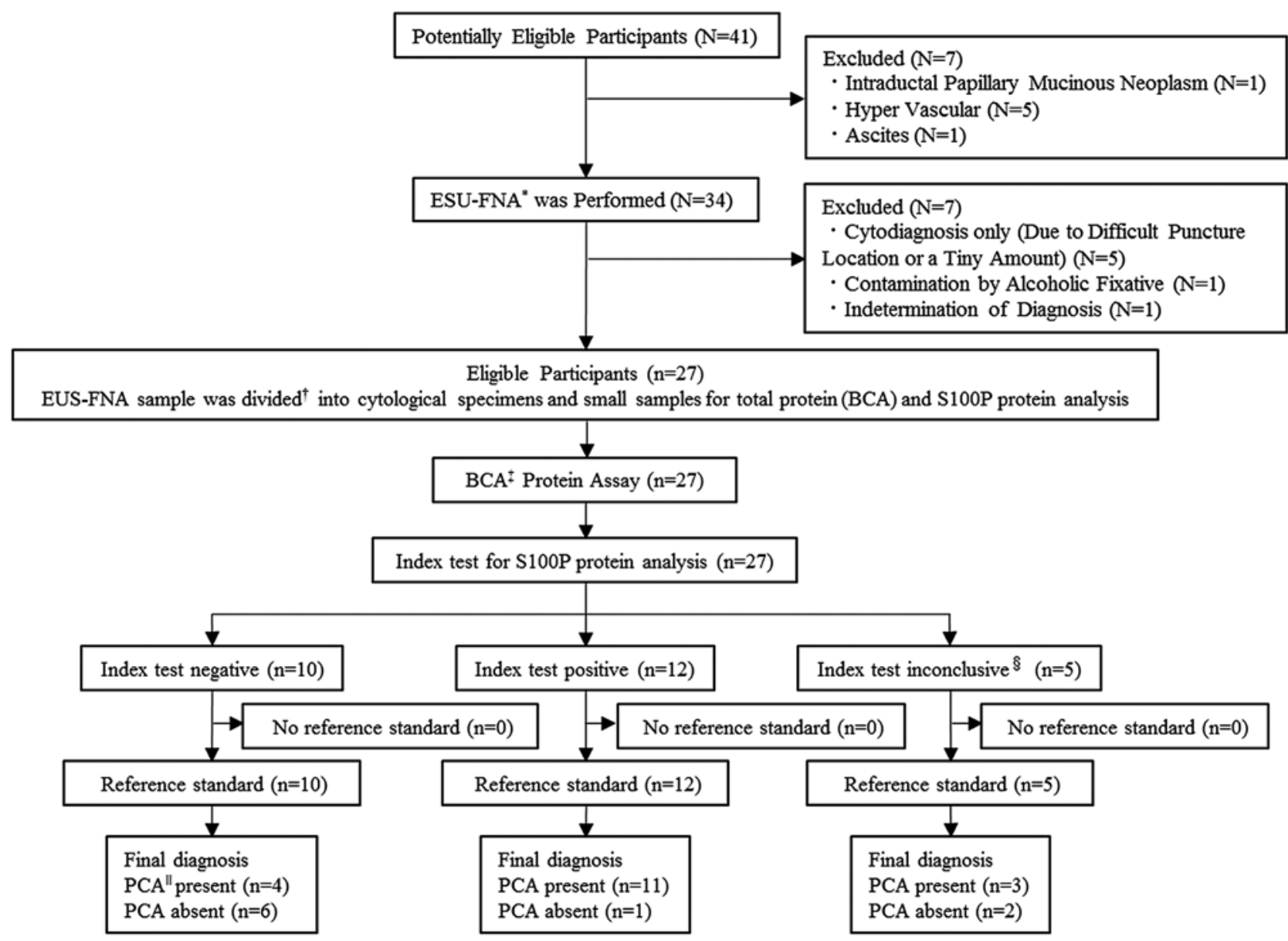

Figure 2. STARD flow diagram of the study. Index test represents S100P analysis with the cut-off value of $99.8 \mathrm{ng} / \mathrm{ml}$. Negative index test is less than the cut-off value and a positive index test is equal to or more than the cut-off value. "Endoscopic ultrasound-guided fine needle aspiration. "The FNA samples for the new device were obtained by 1 pass or by flushing out the residual material with air. A total amount of 1 or 2 passes by EUS-FNA were used for cytological diagnosis. ${ }^{~ B}$ Bicinchoninic acid. ${ }^{~} \mathrm{~S} 100 \mathrm{P}$ protein analysis could not be quantified, due to low total protein concentrations $(<10 \mathrm{mg} / \mathrm{ml})$ which consisted of pancreatic adenocarcinoma in 3 patients, autoimmune pancreatitis in 1 and chronic pancreatitis in 1. "Pancreatic adenocarcinoma.

$7.0 \mu 1(2.0-12.0 \mu 1)$, respectively. The smallest EUS-FNA sample volume was $0.5 \mu \mathrm{l}$ from a patient in the PCA group, however the S100P protein was still assessable at $318.9 \mathrm{ng} / \mathrm{ml}$.

S100P protein concentrations in FNA samples from the PCA group were significantly higher than in the BPL group (404.5 \pm 480.5 vs. $94.0 \pm 149.4 \mathrm{ng} / \mathrm{ml}$, respectively; $\mathrm{P}=0.04$, Fig. 3). In addition, the FNA samples from the PCA group had significantly higher S100P protein concentrations than AsPC-1 cultured cells and AsPC-1 xenograft tumors (404.5 vs. 4.09 vs. $10.85 \mathrm{ng} / \mathrm{ml}$, respectively; $\mathrm{P}<0.05$, Figs. 1 and 3).

Excluding the 5 patients with the inconclusive index tests, linear regression analysis revealed that there was no correlation between the progression of PCA as assessed by the clinical stage and the concentration of the S100P protein ( $\mathrm{n}=15$, $\mathrm{P}=0.142, \mathrm{R}^{2}=0.158$; Fig. $4 \mathrm{~A}$ ). There was also no correlation between the concentrations of the $\mathrm{S} 100 \mathrm{P}$ protein and the total protein $\left(\mathrm{n}=22, \mathrm{P}=0.679, \mathrm{R}^{2}=0.009\right.$, Fig. $\left.4 \mathrm{~B}\right)$, demonstrating the specificity and lack of cross-reactivity with other relevant proteins in the S100P protein assay.

Diagnostic accuracy for the quantitative analysis of the S100P protein, EUS-FNA cytology and both tests combined. A ROC curve analysis was performed using the results of the
22 EUS-FNA samples with conclusive index tests to determine the cut-off value for the $\mathrm{S} 100 \mathrm{P}$ protein concentration for the detection of PCA. The ROC curve analysis determined an S100P protein concentration of $99.8 \mathrm{mg} / \mathrm{ml}$ to be the cut-off value for the detection of PCA (Fig. 5). Using this cut-off value, among the 12 patients with a positive index test, 11 patients were finally diagnosed with PCA, and 1 patient with BPL (S100P protein concentration, $425.8 \mathrm{ng} / \mathrm{ml}$ ). In contrast, among the 10 patients with negative index tests, 4 patients were finally diagnosed with PCA and 6 with BPL (Fig. 2). The sensitivity, specificity, positive predictive value (PPV), NPV, accuracy and AUC of S100P protein concentrations to detect PCA were 73.3, 85.7, 91.7, 60.0, 77.3 and 0.78, respectively (Table II and Fig. 5).

In addition, the sensitivity, specificity, PPV, NPV, accuracy and AUC of EUS-FNA cytology alone to detect PCA in all 27 patients, including the 5 patients with the inconclusive index tests, were $77.8,100,100,69.2,85.2$ and $0.89 \%$, respectively (Table II).

The sensitivity, specificity, PPV, NPV, accuracy and AUC of CEA/CA19-9 to detect PCA, according to our institutional cut-off value $(5.8 \mathrm{ng} / \mathrm{ml}$ of CEA and $37.0 \mathrm{U} / \mathrm{ml}$ of CA19-9), in all 27 patients were 58.8/94.4, 77.7/55.6, 83.3/80.9, 50.0/83.3, $65.4 / 81.4$ and $0.75 / 0.81 \%$, respectively (data not shown). 
Table I. Patient characteristics.

\begin{tabular}{|c|c|}
\hline Characteristics & $\begin{array}{l}\text { Patients } \\
(n=27)\end{array}$ \\
\hline Age, mean (range), years & $70.0(37-86)$ \\
\hline Gender (male/female) & $16 / 11$ \\
\hline \multicolumn{2}{|l|}{ Final diagnosis ${ }^{\mathrm{a}}$} \\
\hline \multicolumn{2}{|l|}{ Pancreatic adenocarcinoma } \\
\hline $\mathrm{IIb}$ & 6 \\
\hline III & 1 \\
\hline IV & 11 \\
\hline Chronic pancreatitis & 3 \\
\hline $\begin{array}{l}\text { Autoimmune pancreatitis } \\
\text { (type } 1)^{c}\end{array}$ & 5 \\
\hline Normal pancreatic tissue & 1 \\
\hline $\begin{array}{l}\text { Size of pancreatic lesion, } \\
\text { mean (range), } \mathrm{mm}\end{array}$ & $29.5(13.0-42.0)$ \\
\hline $\begin{array}{l}\text { No. of needle passes, } \\
\text { mean }(S D)^{d}\end{array}$ & $2.6(0.85)$ \\
\hline \multicolumn{2}{|l|}{ Needle size (gauge) } \\
\hline 19 & 1 \\
\hline 22 & 19 \\
\hline 25 & 4 \\
\hline 22 and 25 & 3 \\
\hline $\begin{array}{l}\mathrm{CEA}^{\mathrm{e}} \text { in } \mathrm{PCA} / \mathrm{BPL}, \\
\text { mean }(\mathrm{SD}), \mathrm{ng} / \mathrm{ml}\end{array}$ & $10.8(11.7) / 4.0(1.6)$ \\
\hline $\begin{array}{l}\text { CA19-9 }{ }^{\mathrm{e}} \text { in } \mathrm{PCA} / \mathrm{BPL}, \\
\text { mean }(\mathrm{SD}), \mu / \mathrm{ml}\end{array}$ & $1465.8(2535.1) / 232.7(407.3)$ \\
\hline
\end{tabular}

Values are the number of patients, unless otherwise stated. ${ }^{\text {aS }}$ Samples from 6 patients were diagnosed by surgical procedure. ${ }^{\text {bB }}$ Based on the American Joint Committee on Cancer TNM Staging of Pancreatic

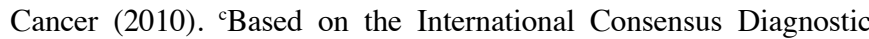
Criteria for Autoimmune Pancreatitis: Guidelines of the International Association of Pancreatology (2011). ${ }^{\mathrm{d} O n e}$ needle pass was used for S100P protein analysis. ${ }^{e}$ Blood tumor markers. SD, standard deviation; PCA, pancreatic adenocarcinoma; BPL, benign pancreatic lesions.

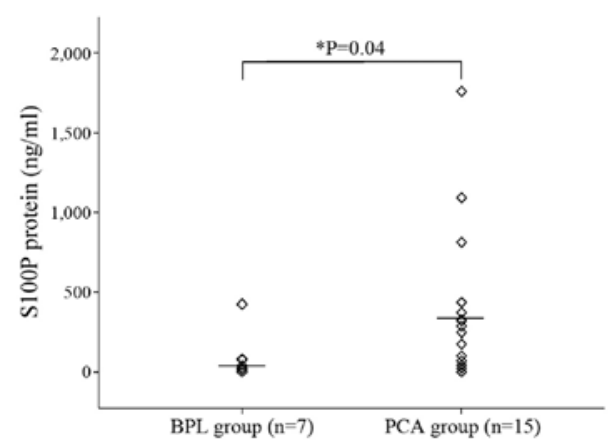

Figure 3. S100P protein concentrations assessed in BPL and PCA from human fine needle aspiration samples $(n=22$, excluding patients with total protein concentrations $<10 \mathrm{mg} / \mathrm{ml}$ ). Scatter plot shows the median $(B P L=38.3 \mathrm{ng} / \mathrm{ml}$, $\mathrm{PCA}=288.7 \mathrm{ng} / \mathrm{ml}$, horizontal line) and the range of the values. The S100P protein concentration was significantly higher in the PCA group than that in the BPL group $\left({ }^{*} \mathrm{P}=0.04\right.$, Mann-Whitney test). BPL, benign pancreatic lesions; PCA, pancreatic adenocarcinoma.
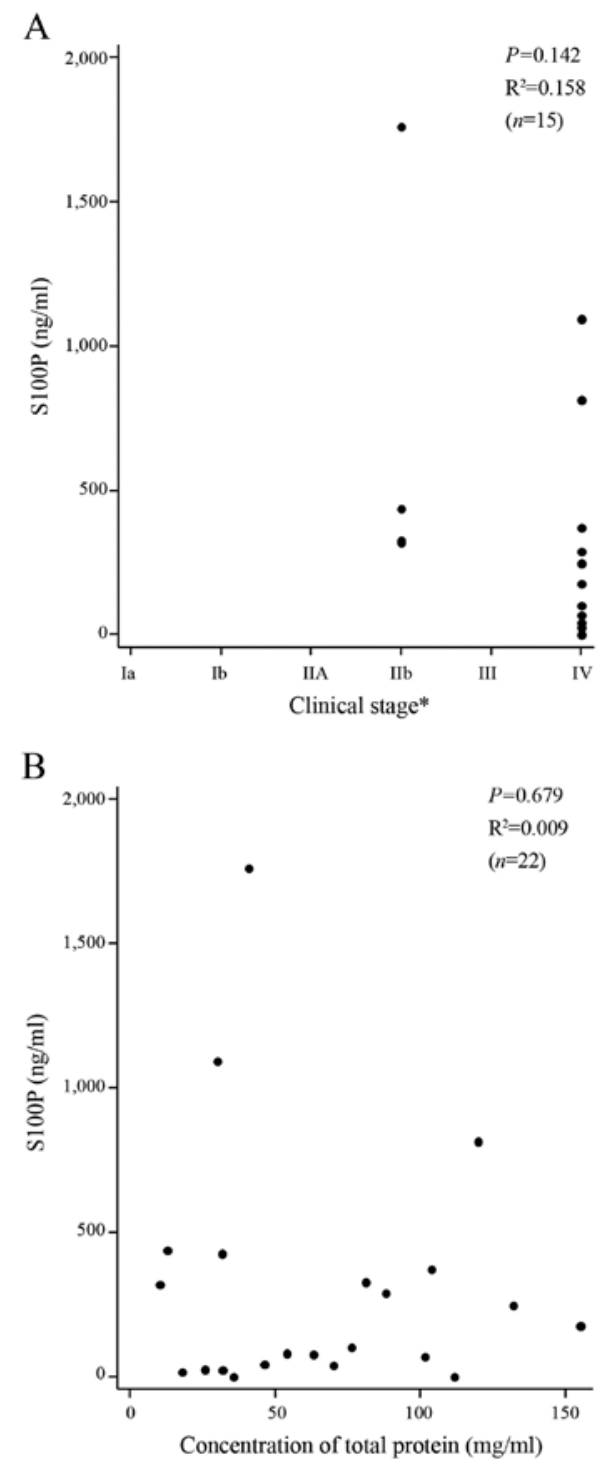

Figure 4. Correlation between S100P protein and (A) clinical stage and (B) total protein concentration analyzed by linear regression test $(n=22)$. (A) The analysis excluded the 12 patients from the benign group and those with low total protein concentrations $(<10 \mathrm{mg} / \mathrm{ml})$ in their EUS-FNA samples. No correlation was observed between S100P concentration and the clinical stage of pancreatic adenocarcinoma. (B) The analysis excludes the 5 patients with low total protein concentrations $(<10 \mathrm{mg} / \mathrm{ml})$ in their EUS-FNA samples. No correlation was observed between total protein and S100P protein concentration, which showed the specificity and lack of crossreactivity with other relevant proteins in the S100P protein assay. EUS-FNA, endoscopic ultrasound-guided fine needle aspiration.

When EUS-FNA cytology was combined with the quantitative analysis of S100P protein, 1 patient with BPL and 2 patients with PCA revealed negative cytology results but positive index tests for $\mathrm{S} 100 \mathrm{P}$ protein. Therefore, the sensitivity, specificity, PPV, NPV, accuracy and AUC of S100P protein concentrations combined with EUS-FNA cytology to detect PCA in the 27 patients were 94.4, 88.9, 94.4, 88.9, 92.6 and $0.92 \%$, respectively (Table II).

\section{Discussion}

To date, evaluation of S100P using tissue samples has been conducted retrospectively using qualitative real-time reverse 
Table II. Diagnostic performances of the quantitative analysis of S100P protein, endoscopic ultrasound-guided fine needle aspiration (EUS-FNA) cytology, and the combination of EUS-FNA cytology and S100P protein quantification for detecting PCA.

\begin{tabular}{lccc}
\hline & S100P protein ELISA ${ }^{\mathrm{a}}(\%)$ & EUS-FNA cytology $^{\mathrm{b}}(\%)$ & Combination $^{\mathrm{b}, \mathrm{c}}(\%)$ \\
\hline Sensitivity (95\% CI) & $73.3(44.9-92.2)$ & $77.8(52.4-93.6)$ & $94.4(75.7-99.1)$ \\
Specificity (95\% CI) & $85.7(42.1-99.6)$ & $100(66.4-100)$ & $88.9(51.8-99.7)$ \\
Positive predictive value (95\% CI) & $91.7(61.5-99.8)$ & $100(76.8-100)$ & $94.4(72.7-99.9)$ \\
Negative predictive value (95\% CI) & $60.0(26.2-87.8)$ & $69.2(38.6-90.9)$ & $88.9(51.8-99.7)$ \\
Accuracy (95\% CI) & $77.3(54.6-99.8)$ & $85.2(66.3-95.8)$ & $92.6(75.7-99.1)$ \\
Area under the curve (95\% CI) & $0.78(0.55-1.00)$ & $0.89(0.79-0.99)$ & $0.92(0.79-1.00)$ \\
\hline
\end{tabular}

${ }^{\mathrm{a}}$ Analysis of the $\mathrm{S} 100 \mathrm{P}$ protein included 22 of the 27 patients; those with a low total protein concentration $(<10 \mathrm{mg} / \mathrm{ml})$ were excluded $(\mathrm{n}=5)$. The cut-off value for the S100P protein concentration was $99.8 \mathrm{ng} / \mathrm{ml} .{ }^{\mathrm{b}}$ All eligible patients $(\mathrm{n}=27)$ were included in the analysis of EUS-FNA cytology alone and in the combination analysis. ${ }^{~} \mathrm{~S} 100 \mathrm{P}$ protein ELISA + EUS-FNA cytology. PCA, pancreatic adenocarcinoma; CI, confidence interval.

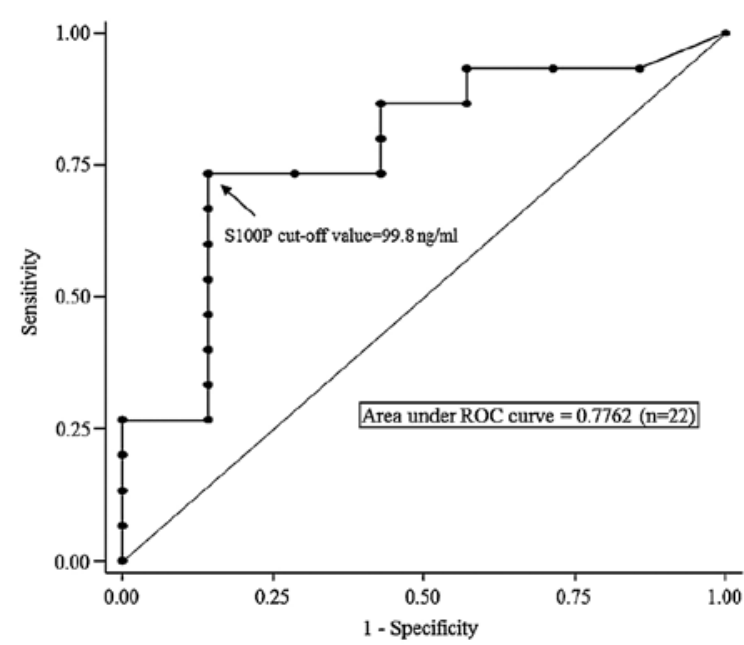

Figure 5. Diagnostic performance of the quantitative S100P protein analysis to diagnose a solid pancreatic mass $(n=22$, excluding patients with total protein concentrations $<10 \mathrm{mg} / \mathrm{ml}$ ). This figure shows the ROC curve and area under the ROC curve value of 0.7762 . The cut-off value of $99.8 \mathrm{ng} / \mathrm{ml}$ is shown by the arrow; this value gives the highest sensitivity and specificity. BPL, benign pancreatic lesion (chronic pancreatitis, autoimmune pancreatitis and normal pancreatic tissue); PCA, pancreatic adenocarcinoma; ROC, receiver operating characteristic.

transcription PCR (RT-PCR) or IHC (10,19,21-27,29). In addition, limitations of real-time RT-PCR using pancreatic tissue have been reported, such as the frequent occurrence of fragmentation or degradation of S100P mRNA due to rich RNase in the pancreas $(4,30)$. In fact, nearly $50 \%$ of FNAs cannot be reliably examined using mRNA analysis (4). Moreover, in order to assess the expression of S100P expression while preventing the fragmentation of mRNA in real-time RT-PCR, the separation of pure PCA cells from strong alkaline pancreatic juice, and the isolation of total cellular RNA from PCA tissue, are required $(4,22,23,26,30,38)$. Thus, evaluation of S100P in pancreatic tissue samples with real-time RT-PCR includes cumbersome preparatory procedures. IHC does not have the limitations of real-time RT-PCR and can be achieved even in EUS-FNA samples. However, IHC can only be performed when adequate amounts of cells are collected, fixed and embedded in paraffin $(4,29)$. Staining edge artifacts and non-specific background staining from contamination can also be a problem with IHC (29). In addition, when EUS-FNA of the pancreatic mass is performed via a transgastric puncture, a diagnosis of PCA should be made carefully, since the EUS-FNA sample could contain gastric tissue, and the normal gastric epithelium is strongly stained by $\operatorname{S100P}(27,29,39)$.

EUS-FNA samples of PCA and in vivo AsPC-1 xenograft tumors showed higher concentrations of S100P protein than in vitro AsPC-1 cultured cells, even though AsPC-1 cultured cells had $100 \%$ pure cellularity. Along with our novel finding of S100P protein production in PANC-1 xenograft tumors, these results suggest that in vivo samples may be more activated to produce S100P protein, and fewer PCA cells may be required to quantify the $\mathrm{S} 100 \mathrm{P}$ protein, compared to in vitro samples. Activation of the S100P production may be associated with various environmental factors. In fact, S100P plays a significant role in cancer activation, proliferation and immortalization (40-43).

In the different cell lines, the high levels of S100P protein in MCF-7 and the low levels in MIA PaCa-2 and PANC-1 cells are in agreement with studies using PCR methods $(20,22,41,44)$ or immunoblotting (42). These findings indicate that the degree of S100P protein production is associated not only with S100P activation, but also the type of cancer cell. S100P activates mitogen-activated protein kinase and nuclear factor- $\kappa B$ pathways through the receptor of advanced glycation end products, and its expression increases tumor growth and metastasis (40-42). Therefore, our results indicate that the activation of PCA and its potential aggressiveness may be evaluated with the quantitative analysis of the S100P protein before surgery or chemotherapy. However, the present study showed no correlation between the clinical stage of PCA and the concentrations of the S100P protein in EUS-FNA-samples, although other studies have proposed that the expression levels of S100P increase during pancreatic cancer progression from the early stage to invasive adenocarcinoma $(21,41)$. Other investigations of cholangiocarcinoma also showed that patients with high expression of S100P had a more advanced stage and a higher mortality and metastasis rate than patients with low expression of S100P (45). The discrepancy between the present study and other research may be partly explained 
by the variety of sample volumes and the concentration of total protein in the EUS-FNA samples. In addition, the present study did not contain early-stage cases of PCA. Therefore, larger sample sizes with early-stage cases may be needed to confirm the prognostic prediction of the S100P protein in EUS-FNA samples.

EUS-FNA samples with low protein concentration assessed by the BCA protein assay showed inconclusive results for the S100P protein. In contrast, the S100P protein was detectable in EUS-FNA samples with a small volume of $0.5 \mu$ l. These results show that the limiting factor for the S100P analysis is not the volume of the sample but the total protein concentration in the EUS-FNA sample. Moreover, the results indicate that EUS-FNA samples with low protein concentrations may only have a few PCA cells, since in some cases a major portion of the EUS-FNA sample can be comprised of other contaminants. However, the pathological assessment of poor cellularity or contamination was virtually impossible in the present study, since EUS-FNA samples were all solubilized for S100P protein analyses due to the ultra-low volume produced by one needle pass.

An average of 2.6 EUS-FNA passes resulted in a high sensitivity of $94.4 \%$ using EUS-FNA cytology combined with S100P protein quantification. Suzuki et al (14) reported an association between the sensitivity and the pass number with a 25-gauge needle for EUS-FNA for solid pancreatic lesions. The sensitivity was increased by adding passes; $53 \%$ by 1 pass, $73 \%$ by 2 passes, $87 \%$ by 3 passes, and $93 \%$ by 4 passes. It should be noted, however, that our pilot study cannot be compared with Suzuki's study, since the study designs and sample sizes varied. However, our average of 2.6 passes with a high diagnostic value indicates that the combination of EUS-FNA cytology plus S100P protein assessment produces a high sensitivity while decreasing the number of passes as well as a variety of risks, such as bleeding, pancreatitis, peritoneal dissemination, procedure time, costs and patient discomfort. In addition, our results show a high NPV (88.6\%) for the combination analysis, which indicates that this method holds the potential for improving the limitations of EUS-FNA with low NPV (17).

The significant difference between the PCA and BPL groups for the S100P protein concentrations indicates that our quantitative S100P analysis may be a promising new method for the diagnosis of PCA from EUS-FNA samples. This analysis combined with EUS-FNA cytology showed high performance, while the cut-off value could be used to evaluate S100P protein concentrations in ultra-low volume FNA samples as an auxiliary diagnosis. Our results correspond with past studies using RT-PCR or IHC that demonstrated that $\mathrm{S} 100 \mathrm{P}$ is not highly expressed in chronic pancreatitis, normal pancreatic tissue, fibrous stroma or other necrotic tissue, unlike PCA cells $(18-20,22,27,46,47)$. When the cut-off value for the S100P protein was set at $99.8 \mathrm{ng} / \mathrm{ml}, 1$ out of 5 patients with AIP showed a high concentration of S100P protein $(425.8 \mathrm{ng} / \mathrm{ml})$. In this patient, our novel quantitative analysis possibly detected S100P protein originating from inflammatory cells such as leukocytes, since mRNA levels of the S100P protein are moderately high in leukocytes (39), and pathologically, type I AIP has many inflammatory cells, as its histopathological name, lymphoplasmacytic sclerosing pancreatitis, suggests (48).
The following represent potential limitations of the present study. The present study was a single-center based trial with a small sample size. Even though the cytology sample volumes had, on average, 1.6 more passes than the S100P protein analysis samples (1 pass), the accuracy of the cytological diagnosis may be affected to some degree. In the present study, results for EUS-FNA cytology alone showed a lower sensitivity (77.8\%) compared with previous studies $(1,16,17)$. The splitting method used in the present study may decrease the volume of sample for cytology. However, there is a potential difference in the puncture location and sample component for the cytology samples compared to the protein analysis samples.

In conclusion, we successfully established a novel, simple quantitative test for detecting small amounts of PCA cells in tiny samples of EUS-FNA by means of a high sensitivity sandwich ELISA for the S100P protein. Secondly, the S100P protein concentrations differed between cell lines, xenograft tumors and human EUS-FNA samples. Thirdly, quantification of the S100P protein can provide reliable discrimination between PCA and BPL, as a simple and objective method for an auxiliary diagnosis using the cut-off value we established. Finally, the combination of EUS-FNA cytology plus S100P protein quantification showed high accuracy for diagnosing PCA from pancreatic masses by EUS-FNA specimens, in the setting of a prospective continuous series.

\section{Acknowledgements}

We would like to thank Professor Masato Matsushima and Dr Masako Nishikawa for their assistance with the statistical analyses included in the present study. Special thanks are expressed to Yumi Takagi for technical assistance and performing the ELISA assays. In addition, we would like to thank the Department of Surgery and the Division of Gastroenterology and Hepatology for patient recruitment. The manuscript has been revised by a specialist native English editor, Fiona Wylie with a PhD in Biomedical Sciences.

\section{References}

1. Puli SR, Bechtold ML, Buxbaum JL and Eloubeidi MA: How good is endoscopic ultrasound-guided fine-needle aspiration in diagnosing the correct etiology for a solid pancreatic mass?: A meta-analysis and systematic review. Pancreas 42: 20-26, 2013.

2. Savides TJ, Donohue M, Hunt G, Al-Haddad M, Aslanian H, Ben-Menachem T, Chen VK, Coyle W, Deutsch J, DeWitt J, et al: EUS-guided FNA diagnostic yield of malignancy in solid pancreatic masses: A benchmark for quality performance measurement. Gastrointest Endosc 66: 277-282, 2007.

3. Dina R, Tran-Dang MA, Mauri F, Gudi M, Cohen P, Ahmad R, Batav L, Vlavianos P and Spalding D: Pancreatobiliary cytology in the multidisciplinary setting. Cytopathology 24: 150-158, 2013.

4. Bournet B, Gayral M, Torrisani J, Selves J, Cordelier P and Buscail L: Role of endoscopic ultrasound in the molecular diagnosis of pancreatic cancer. World J Gastroenterol 20: 10758-10768, 2014.

5. Fritscher-Ravens A, Brand L, Knöfel WT, Bobrowski C, Topalidis T, Thonke F, de Werth A and Soehendra N: Comparison of endoscopic ultrasound-guided fine needle aspiration for focal pancreatic lesions in patients with normal parenchyma and chronic pancreatitis. Am J Gastroenterol 97: 2768-2775, 2002.

6. Varadarajulu S, Tamhane A and Eloubeidi MA: Yield of EUS-guided FNA of pancreatic masses in the presence or the absence of chronic pancreatitis. Gastrointest Endosc 62: 728-736, quiz $751,753,2005$. 
7. Krishna NB, Mehra M,Reddy AV and Agarwal B: EUS/EUS-FNA for suspected pancreatic cancer: Influence of chronic pancreatitis and clinical presentation with or without obstructive jaundice on performance characteristics. Gastrointest Endosc 70: 70-79, 2009.

8. Ribeiro A, Peng J, Casas C and Fan YS: Endoscopic ultrasound guided fine needle aspiration with fluorescence in situ hybridization analysis in 104 patients with pancreatic mass. J Gastroenterol Hepatol 29: 1654-1658, 2014.

9. Lin F and Staerkel G: Cytologic criteria for well differentiated adenocarcinoma of the pancreas in fine-needle aspiration biopsy specimens. Cancer 99: 44-50, 2003.

10. Dim DC, Jiang F, Qiu Q, Li T, Darwin P, Rodgers WH and Peng HQ: The usefulness of S100P, mesothelin, fascin, prostate stem cell antigen, and 14-3-3 sigma in diagnosing pancreatic adenocarcinoma in cytological specimens obtained by endoscopic ultrasound guided fine-needle aspiration. Diagn Cytopathol 42: 193-199, 2014.

11. Siddiqui AA, Brown LJ, Hong SK, Draganova-Tacheva RA, Korenblit J, Loren DE, Kowalski TE and Solomides C: Relationship of pancreatic mass size and diagnostic yield of endoscopic ultrasound-guided fine needle aspiration. Dig Dis Sci 56: 3370-3375, 2011

12. Iglesias-Garcia J, Dominguez-Munoz JE, Abdulkader I, Larino-Noia J, Eugenyeva E, Lozano-Leon A and Forteza-Vila J: Influence of on-site cytopathology evaluation on the diagnostic accuracy of endoscopic ultrasound-guided fine needle aspiration (EUS-FNA) of solid pancreatic masses. Am J Gastroenterol 106: 1705-1710, 2011.

13. Camellini L, Carlinfante G, Azzolini F, Iori V, Cavina M, Sereni G, Decembrino F, Gallo C, Tamagnini I, Valli R, et al: A randomized clinical trial comparing $22 \mathrm{G}$ and $25 \mathrm{G}$ needles in endoscopic ultrasound-guided fine-needle aspiration of solid lesions. Endoscopy 43: 709-715, 2011.

14. Suzuki R, Irisawa A, Bhutani MS, Hikichi T, Takagi T, Sato A, Sato M, Ikeda T, Watanabe K, Nakamura J, et al: Prospective evaluation of the optimal number of 25-gauge needle passes for endoscopic ultrasound-guided fine-needle aspiration biopsy of solid pancreatic lesions in the absence of an onsite cytopathologist. Dig Endosc 24: 452-456, 2012.

15. Yasuda I, Iwashita T and Doi S: Tips for endoscopic ultrasoundguided fine needle aspiration of various pancreatic lesions. J Hepatobiliary Pancreat Sci 21: E29-E33, 2014.

16. Hewitt MJ, McPhail MJ, Possamai L, Dhar A, Vlavianos P and Monahan KJ: EUS-guided FNA for diagnosis of solid pancreatic neoplasms: A meta-analysis. Gastrointest Endosc 75: 319-331, 2012.

17. Hartwig W, Schneider L, Diener MK, Bergmann F, Büchler MW and Werner J: Preoperative tissue diagnosis for tumours of the pancreas. Br J Surg 96: 5-20, 2009.

18. Logsdon CD, Simeone DM, Binkley C, Arumugam T, Greenson JK, Giordano TJ, Misek DE, Kuick R and Hanash S: Molecular profiling of pancreatic adenocarcinoma and chronic pancreatitis identifies multiple genes differentially regulated in pancreatic cancer. Cancer Res 63: 2649-2657, 2003.

19. Crnogorac-Jurcevic T, Missiaglia E, Blaveri E, Gangeswaran R, Jones M, Terris B, Costello E, Neoptolemos JP and Lemoine NR: Molecular alterations in pancreatic carcinoma: Expression profiling shows that dysregulated expression of S100 genes is highly prevalent. J Pathol 201: 63-74, 2003.

20. Sato N, Fukushima N, Matsubayashi H and Goggins $M$ Identification of maspin and S100P as novel hypomethylation targets in pancreatic cancer using global gene expression profiling. Oncogene 23: 1531-1538, 2004.

21. Dowen SE, Crnogorac-Jurcevic T, Gangeswaran R, Hansen M, Eloranta JJ, Bhakta V, Brentnall TA, Lüttges J, Klöppel G and Lemoine NR: Expression of S100P and its novel binding partner S100PBPR in early pancreatic cancer. Am J Pathol 166: 81-92, 2005.

22. Ohuchida K, Mizumoto K, Egami T, Yamaguchi H, Fujii K, Konomi H, Nagai E, Yamaguchi K, Tsuneyoshi M and Tanaka M: S100P is an early developmental marker of pancreatic carcinogenesis. Clin Cancer Res 12: 5411-5416, 2006.

23. Chen Y, Zheng B, Robbins DH, Lewin DN, Mikhitarian K, Graham A, Rumpp L, Glenn T, Gillanders WE, Cole DJ, et al: Accurate discrimination of pancreatic ductal adenocarcinoma and chronic pancreatitis using multimarker expression data and samples obtained by minimally invasive fine needle aspiration. Int J Cancer 120: 1511-1517, 2007.
24. Lin F, Shi J, Liu H, Hull ME, Dupree W, Prichard JW, Brown RE, Zhang J, Wang HL and Schuerch C: Diagnostic utility of S100P and von Hippel-Lindau gene product (pVHL) in pancreatic adenocarcinoma-with implication of their roles in early tumorigenesis. Am J Surg Pathol 32: 78-91, 2008.

25. Kosarac O, Takei H,Zhai QJ, Schwartz MR and Mody DR: S100P and XIAP expression in pancreatic ductal adenocarcinoma: Potential novel biomarkers as a diagnostic adjunct to fine needle aspiration cytology. Acta Cytol 55: 142-148, 2011.

26. Bournet B, Pointreau A, Souque A, Oumouhou N, Muscari F, Lepage B, Senesse P, Barthet M, Lesavre N, Hammel P, et al: Gene expression signature of advanced pancreatic ductal adenocarcinoma using low density array on endoscopic ultrasound-guided fine needle aspiration samples. Pancreatology 12: 27-34, 2012.

27. Liu H, Shi J, Anandan V, Wang HL, Diehl D, Blansfield J, Gerhard G and Lin F: Reevaluation and identification of the best immunohistochemical panel (pVHL, Maspin, S100P, IMP-3) for ductal adenocarcinoma of the pancreas. Arch Pathol Lab Med 136: 601-609, 2012.

28. Hu H, Zhang Q, Huang C, Shen Y, Chen X, Shi X and Tang W: Diagnostic value of S100P for pancreatic cancer: A metaanalysis. Tumour Biol 35: 9479-9485, 2014.

29. Deng H, Shi J, Wilkerson M, Meschter S, Dupree W and Lin F: Usefulness of S100P in diagnosis of adenocarcinoma of pancreas on fine-needle aspiration biopsy specimens. Am J Clin Pathol 129: 81-88, 2008.

30. Augereau C, Lemaigre FP and Jacquemin P: Extraction of highquality RNA from pancreatic tissues for gene expression studies. Anal Biochem 500: 60-62, 2016.

31. The National Cancer Institute (NCI): Cancer Clinical Trials: The Basic Workbook [NCI Web site]. September, 2002. Available at: https://accrualnet.cancer.gov/sites/accrualnet.cancer.gov/ files/BasicsWorkbook_m.pdf. Accessed October 15, 2016.

32. Imazu H, Uchiyama Y, Kakutani H, Ikeda K, Sumiyama K, Kaise M, Omar S, Ang TL and Tajiri H: A prospective comparison of EUS-guided FNA using 25-gauge and 22-gauge needles. Gastroenterol Res Pract 2009: 546390, 2009.

33. Des Jarlais DC, Lyles C and Crepaz N; TREND Group: Improving the reporting quality of nonrandomized evaluations of behavioral and public health interventions: The TREND statement. Am J Public Health 94: 361-366, 2004.

34. Bossuyt PM, Reitsma JB, Bruns DE, Gatsonis CA, Glasziou PP, Irwig L, Lijmer JG, Moher D, Rennie D, de Vet HC, et al; STARD Group: STARD 2015: An Updated List of Essential Items for Reporting Diagnostic Accuracy Studies. Clin Chem 61: 1446-1452, 2015

35. Pitman MB, Centeno BA, Ali SZ, Genevay M, Stelow E, Mino-Kenudson M, Fernandez-del Castillo C, Max Schmidt C, Brugge W and Layfield L; Papanicolaou Society of Cytopathology: Standardized terminology and nomenclature for pancreatobiliary cytology: The Papanicolaou Society of Cytopathology guidelines. Diagn Cytopathol 42: 338-350, 2014.

36. Pitman MB and Layfield LJ: Guidelines for pancreaticobiliary cytology from the Papanicolaou Society of Cytopathology: A review. Cancer Cytopathol 122: 399-411, 2014.

37. Layfield LJ and Pitman MB: The Papanicolaou Society of Cytopathology guidelines for pancreaticobiliary tract cytology: A new installment in the 'Bethesda' style of guidelines from the Papanicolaou Society of Cytopathology. Diagn Cytopathol 42: 283-284, 2014

38. Lekanne Deprez RH, Fijnvandraat AC, Ruijter JM and Moorman AF: Sensitivity and accuracy of quantitative real-time polymerase chain reaction using SYBR green I depends on cDNA synthesis conditions. Anal Biochem 307: 63-69, 2002.

39. Parkkila S, Pan PW, Ward A, Gibadulinova A, Oveckova I, Pastorekova S, Pastorek J, Martinez AR, Helin HO and Isola J: The calcium-binding protein S100P in normal and malignant human tissues. BMC Clin Pathol 8: 2-6890-8-2, 2008.

40. Arumugam T, Simeone DM, Schmidt AM and Logsdon CD: S100P stimulates cell proliferation and survival via receptor for activated glycation end products (RAGE). J Biol Chem 279: 5059-5065, 2004.

41. Arumugam T, Simeone DM, Van Golen K and Logsdon CD: S100P promotes pancreatic cancer growth, survival, and invasion. Clin Cancer Res 11: 5356-5364, 2005.

42. Arumugam T, Ramachandran V and Logsdon CD: Effect of cromolyn on S100P interactions with RAGE and pancreatic cancer growth and invasion in mouse models. J Natl Cancer Inst 98: 1806-1818, 2006. 
43. Arumugam T and Logsdon CD: S100P: A novel therapeutic target for cancer. Amino Acids 41: 893-899, 2011.

44. Zhou C, Zhong Q, Rhodes LV, Townley I, Bratton MR, Zhang Q, Martin EC, Elliott S, Collins-Burow BM, Burow ME, et al: Proteomic analysis of acquired tamoxifen resistance in MCF-7 cells reveals expression signatures associated with enhanced migration. Breast Cancer Res 14: R45, 2012.

45. Wu Z, Boonmars T, Nagano I, Boonjaraspinyo S, Srinontong P, Ratasuwan P, Narong K, Nielsen PS and Maekawa Y: Significance of S100P as a biomarker in diagnosis, prognosis and therapy of opisthorchiasis-associated cholangiocarcinoma. Int J Cancer 138: 396-408, 2016.

46. Missiaglia E, Blaveri E, Terris B, Wang YH, Costello E, Neoptolemos JP, Crnogorac-Jurcevic T and Lemoine NR: Analysis of gene expression in cancer cell lines identifies candidate markers for pancreatic tumorigenesis and metastasis. Int J Cancer 112: 100-112, 2004.
47. Fukushima N, Sato N, Prasad N, Leach SD, Hruban RH and Goggins M: Characterization of gene expression in mucinous cystic neoplasms of the pancreas using oligonucleotide microarrays. Oncogene 23: 9042-9051, 2004.

48. Shimosegawa T, Chari ST, Frulloni L, Kamisawa T, Kawa S, Mino-Kenudson M, Kim MH, Klöppel G, Lerch MM, Löhr M, et al; International Association of Pancreatology: International consensus diagnostic criteria for autoimmune pancreatitis: Guidelines of the International Association of Pancreatology. Pancreas 40: 352-358, 2011. 